\title{
A comparative study of resource allocation in Pteridium in different Brazilian ecosystems and its relationship with European studies
}

\author{
Silva Matos, DM. ${ }^{a *}$, Xavier, RO. ${ }^{a}$, Tiberio, FCS. ${ }^{a}$ and Marrs, $R H .{ }^{b}$ \\ ${ }^{a}$ Departamento de Hidrobiologia, Universidade Federal de São Carlos - UFSCar, Rod. Washington Luis, \\ Km 235, CP 676, CEP 13565-905, São Carlos, SP, Brazil \\ ${ }^{\mathrm{b}} \mathrm{School}$ of Environmental Sciences, University of Liverpool, Liverpool, L69 3GP, UK \\ *e-mail: dmatos@ufscar.br
}

Received: October 5, 2012 - Accepted: December 3, 2012 - Distributed: February 28, 2012

(With 2 figures)

\begin{abstract}
Pteridium is a cosmopolitan genus that acts as an invasive species in many parts of the world. Most research on this genus has occurred in Europe, and there is a lack of data on it from South America, in spite of causing considerable conservation problems. We compared the biomass allocation of P. esculentum subsp. arachnoideum in two ecosystems in Brazil - Atlantic forest and Brazilian savanna. We measured the biomass of fronds, rhizomes and above-ground litter. We also compared the density, length and biomass of fronds from this Brazilian study with similar data of $P$. esculentum subsp. arachnoideum derived from Venezuela and P. aquilinum from Europe. P. esculentum subsp. arachnoideum showed a wide response range. We found a negative relationship between frond and necromass, indicating a negative feedback effect, while a positive relationship was observed between frond and rhizome biomass. The continental comparison of relationships showed that Pteridium responds in a different way in both Brazil and Europe, and that in Brazil fronds tend to be longer and heavier, presumably as a result of the continuous growing season in South America while is shortened in Europe by frost. The paper shows the ability of Pteridium to adapt to different ecosystems.
\end{abstract}

Keywords: bracken, resource partitioning, Atlantic Forest, Cerrado, biomass.

\section{Estudo comparativo da alocação de recurso em Pteridium em diferentes ecossistemas brasileiros e sua relação com estudos na europa}

\begin{abstract}
Resumo
Pteridium é um gênero cosmopolita que inclui espécies invasoras em várias partes do mundo. Os estudos sobre o gênero têm ocorrido principalmente na Europa, e existem poucas informações para as espécies que ocorrem na América do Sul. Nesse estudo comparamos a alocação de biomassa de P. esculentum subsp. arachnoideum em dois ecossistemas brasileiros - Mata Atlântica e Cerrado - em cada um dos quais medimos a biomassa nos rametas, nos rizomas e na serapilheira. Comparamos, também, a densidade, comprimento e biomassa dos rametas com informações obtidas sobre P. esculentum subsp. arachnoideum na Venezuela e P. aquilinum na Europa. P. esculentum subsp. arachnoideum apresentou respostas distintas. Encontramos uma relação negativa entre a biomassa de rametas e da serapilheira, indicando uma retro-alimentação negativa, enquanto houve uma relação positiva entre a biomassa dos rametas e dos rizomas. A comparação das relações entre os continentes indicou que Pteridium responde diferentemente no Brazil e na Europa, e também que no Brasil os rametas são maiores e contêm mais biomassa, possivelmente devido à estação de crescimento contínua, enquanto na Europa o crescimento é limitado pelas baixas temperaturas. Esse estudo demonstra o sucesso adaptativo de Pteridium em diferentes ecossistemas.
\end{abstract}

Palavras-chave: samambaião, alocação de recursos, Mata Atlântica, Cerrado, biomassa.

\section{Introduction}

Considering the impact that invasive species has been put on biological diversity all over the world, understanding how these species colonize successfully different ecosystems is a central goal in ecology. Invasive plant species, for example, are able to maintain or even increase its fitness across a range of environmental conditions through phenotypic plasticity (Richards et al, 2006; Rejmanek, 2011). Phenotypic plasticity refers to the ability of plants to modify its phenotype in

response to environmental changes, with physiological and/or morphological adjustments at the individual level. Most classical examples of phenotypic plasticity are based on morphological traits: variations of leaves in response to variation of sun exposure (Bradshaw, 1963); changes on root growth in response to different concentrations of nutrients in heterogeneous soils (Miner et al., 2005; Jiménez-Ambriz et al., 2007); and differences in resource 
allocation, through changes in the allometric trajectories in response to environmental conditions (Carnier, 1991; Fan et al., 2009; Weiner, 2004).

Despite the controversial about resource allocation strategies (McConnaughay and Coleman, 1999; Fan et al., 2009), two main hypothesis have been proposed to describe biomass allocation (Muller et al., 2000; Shipley and Meziane, 2002; Niklas, 2005; McCarthy and Enquist, 2007; Yang et al., 2009): 1) the optimal partitioning hypothesis considers that plants allocate proportionally more biomass to a given organ to maximize their growth in response to environmental changes (Yang et al., 2009), while according to 2) the isometric allocation hypothesis the allocation does not change in response to environmental variations (Niklas, 2005; Yang et al., 2009). Thus, considering the relationship between the above and belowground biomass, the slope of the regression is 1.0 in case of isometric partitioning and variable for the optimal partitioning pattern.

Variations on biomass allocation can affect survival, growth and reproduction of individual plants and consequently shape the establishment and invasiveness in different habitats. Pteridium is a cosmopolitan genus occurring in a wide range of habitats worldwide, except in the polar regions (Marrs and Watt, 2006). Over much of its range it is a serious weed problem. Although a great deal is known about Pteridium ecology, its form and function, and control measures, most of this has been derived from studies in Europe about Pteridium aquilinum (L.) Kuhn (Marrs and Watt, 2006), and until recently there has been much less data from South America (Alonso-Amelot and Rodulfo-Baechler, 1996; Thomson and Alonso-Amelot, 2002; Hartig and Beck, 2003; Alonso-Amelot and OliverosBastidas, 2005; Silva and Silva Matos, 2006; Silva Matos and Belinato, 2010; Miatto et al., 2011). This lack of data from South America is surprising because Pteridium esculentum arachnoideum abundance is causing concern for animal health across the continent (França et al., 2002; Marçal et al., 2002; Marçal, 2003). Thus, from both ecological and economic viewpoints there is a need to collect data on P. esculentum subsp. arachnoideum from South America and to relate this to the existing data available from Europe. This comparison would clearly facilitate the exchange of management practices for controlling this aggressive weed. The ideal way to study species performance across regions in the first instance is to compare biomass allocation data. Accordingly, here the allocation strategies of Pteridium were measured in Brazil, and compared to available literature data derived from elsewhere in South America, but mainly from the Europe. We looked for patterns of correlations in biomass allocation between two major plant pools that could reflect functional linkages between some species attributes. Such allocation differences would result because resource allocation to one organ or function would not be available for use by other organs or functions (Stuefer et al., 2002; Weiner, 2004).

In temperate climates Pteridium produces large stands with a dense canopy of green fronds, recruitment is rare in nature; patch expansion is achieved by vegetative growth through the rhizomes, the rate of frond decomposition is low and the litter layer can be very deep (Marrs and Watt, 2006). Whilst litter would normally be considered as part of the necromass, it provides a major ecological function for the species in terms of modification of the microclimate through frost protection (Marrs and Watt, 2006) and in suppressing the ingress of other species (Ghorbani et al., 2006; Marrs and Watt, 2006). We hypothesized that as Pteridium is considered an aggressive and invasive plant, changes in biomass allocation would be expected due to climatic differences representing the adaptation of this genus to occupy different ecosystems. In this case the optimal partitioning hypothesis (Yang et al., 2009) would be accepted. Therefore, we aimed to answer the two following questions: (1) is the biomass allocation similar in two contrasting Brazilian ecosystems? (2) Are the European and South American Pteridium comparable, so that management control strategies derived in one region might be applicable elsewhere?

\section{Material and Methods}

\subsection{Measurement of biomass allocation in Pteridium esculentum subsp. arachnoideum}

Pteridium esculentum (G.Forst.) Cockayne subsp. arachnoideum (Kaulf.) J.A.Thomson, Dennstaedtiaceae, is a neotropical species within the Pteridium genus found in Brazil, according to Thomson (2012). The biomass of this species was sampled from july to september in two different Brazilian ecosystems, Atlantic Forest and Cerrado (hereafter named as Savanna) located in eight biological reserves (see Table 1). The Atlantic Forest is one of world most luxurious and important ecosystems for conservation because of its high biodiversity and high proportion of endemic species (Myers et al. 2000). Nowadays, it is reduced to $8 \%$ of its original area (Fundação SOS Mata Atlântica; INPE, 2009). Brazilian Savanna is the world's most biologically-rich savanna ecosystems (The Nature Conservancy, 2010); originally it occupied $21 \%$ of the Brazilian territory (about 2 million $\mathrm{km}^{2}$ ), however at least $48 \%$ percent of it has already been severely degraded (Pereira and Gama, 2010). In both ecosystems, P. esculentum subsp. arachnoideum has been described as invasive affecting the structure of their plant community Silva Matos et al. 2002, 2005; Silva and Silva Matos 2006; Silva Matos and Belinato, 2010; Miatto et al., 2011).

Within eight biological reserves covering the two ecosystems (Atlantic rain forest, $\mathrm{n}=4$; Savanna, $\mathrm{n}=6$, see Table 1 ), ten sites covered by $P$. esculentum subsp. arachnoideum were identified. Within each site, five replicate sampling positions were located randomly. At each of these positions a $0.5 \times 0.5 \times 0.5 \mathrm{~m}$ quadrat was positioned and all living fronds and litter biomass (hereafter named as necromass) was harvested, and the length of all fronds were measured. In this paper, we will hereafter use the term frond to represent collectively all fronds from each individual position. A soil pit was then dug and all rhizomes were removed by hand from the excavated soil 
Table 1. Description of the ten study sites across the two Brazilian ecosystems.

\begin{tabular}{|c|c|c|c|c|c|}
\hline Ecosystem & Study site location & $\begin{array}{l}\text { Longitude, } \\
\text { latitude }\end{array}$ & $\begin{array}{l}\text { Altitude } \\
\text { (m) }\end{array}$ & $\begin{array}{c}\text { Climate } \\
\text { Mean temperature }\left({ }^{\circ} \mathrm{C}\right) \\
\text { Mean-rainfall }(\mathrm{mm} / \mathrm{year})\end{array}$ & Soil description \\
\hline \multirow[t]{4}{*}{$\begin{array}{l}\text { Atlantic } \\
\text { Forest }\end{array}$} & $\begin{array}{l}\text { Parque Estadual Carlos } \\
\text { Botelho (PECB) }\end{array}$ & 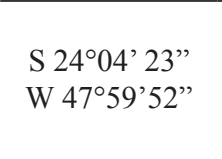 & 710 & $\begin{array}{c}18-20 \\
1,500-2,200\end{array}$ & $\begin{array}{c}\text { Hydromorphic, } \\
\text { yellow-red } \\
\text { latosols and } \\
\text { podzol }\end{array}$ \\
\hline & $\begin{array}{c}\text { Parque Estadual Campina } \\
\text { do Encantado (PECE) }\end{array}$ & $\begin{array}{l}\mathrm{S} 24^{\circ} 39^{\prime} 029^{\prime \prime} \\
\mathrm{W} 47^{\circ} 49^{\prime} 835^{\prime}\end{array}$ & 12 & $\begin{array}{c}17.5-27 \\
1,600-2,200\end{array}$ & $\begin{array}{l}\text { Quartzarenic } \\
\text { Neosol }\end{array}$ \\
\hline & $\begin{array}{l}\text { Parque Estadual de } \\
\text { Jacupiranga (PEJ) }\end{array}$ & $\begin{array}{l}\text { S 2430' } 146^{\prime \prime}, \\
\text { W 4750'303', }\end{array}$ & 548 & $\begin{array}{c}17-35 \\
1,600-2,200\end{array}$ & $\begin{array}{c}\text { Hydromorphic, } \\
\text { yellow-red } \\
\text { latosols and } \\
\text { podzol }\end{array}$ \\
\hline & $\begin{array}{l}\text { Parque Estadual Ilha do } \\
\text { Cardoso (PEIC) }\end{array}$ & $\begin{array}{l}\text { S } 25^{\circ} 12^{\prime} 45^{\prime \prime} \\
\text { W } 47^{\circ} 59^{\prime} 48^{\prime \prime}\end{array}$ & 5 & $\begin{array}{c}21.2 \\
3,000\end{array}$ & Sandy soils \\
\hline \multirow[t]{6}{*}{ Savanna } & $\begin{array}{l}\text { Reserva de Cerrado da } \\
\text { UFSCar, adjacent to the } \\
\text { riparian forest (UFSCar1) }\end{array}$ & $\begin{array}{l}\text { S } 21^{\circ} 57^{\prime} 971^{\prime \prime} \\
\text { W } 47^{\circ} 52^{\prime} 150^{\prime \prime}\end{array}$ & 860 & $\begin{array}{c}22.1 \\
1,339\end{array}$ & $\begin{array}{l}\text { Alic red-yellow } \\
\text { and distrophic } \\
\text { red-yellow } \\
\text { latosols }\end{array}$ \\
\hline & $\begin{array}{l}\text { Reserva de Cerrado da } \\
\text { UFSCar } 800 \mathrm{~m} \text { from the } \\
\text { riparian forest (UFSCar 2) }\end{array}$ & $\begin{array}{l}\mathrm{S} 21^{\circ} 58^{\prime} 125^{\prime \prime} \\
\mathrm{W} 47^{\circ} 51^{\prime} 882^{\prime \prime}\end{array}$ & 866 & $\begin{array}{c}22.1 \\
1,339\end{array}$ & $\begin{array}{l}\text { Alic red-yellow } \\
\text { and distrophic } \\
\text { red-yellow } \\
\text { latosols }\end{array}$ \\
\hline & $\begin{array}{l}\text { Estação Ecológica de } \\
\text { Itirapina (EEI) }\end{array}$ & $\begin{array}{l}\text { S } 22^{\circ} 12^{\prime} 382^{\prime \prime}, \\
\text { W } 47^{\circ} 55^{\prime} 840^{\prime \prime}\end{array}$ & 737 & $\begin{array}{l}22.0 \\
1,339\end{array}$ & $\begin{array}{l}\text { Quartzarenic } \\
\text { Neosol }\end{array}$ \\
\hline & $\begin{array}{c}\text { Parque Estadual de Porto } \\
\text { Ferreira (PEPF) }\end{array}$ & $\begin{array}{l}\mathrm{S} 21^{\circ} 50^{\prime} \\
\mathrm{W} 47^{\circ} 28^{\prime}\end{array}$ & 540 & $\begin{array}{c}17.2-22.8 \\
1,300\end{array}$ & $\begin{array}{l}\text { Distrophic red- } \\
\text { yellow latosols }\end{array}$ \\
\hline & $\begin{array}{l}\text { Reserva Biologica do IBGE } \\
\text { (Brasilia) (RECOR 1) }\end{array}$ & 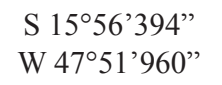 & 1120 & $\begin{array}{c}23 \\
1,527\end{array}$ & $\begin{array}{l}\text { Dark-red } \\
\text { latosols }\end{array}$ \\
\hline & $\begin{array}{l}\text { Reserva Biologica do IBGE } \\
\text { (Brasilia) (RECOR 2) }\end{array}$ & $\begin{array}{l}\text { S 1556'313”' } \\
\text { Wo 4752’026”' }\end{array}$ & 1135 & $\begin{array}{c}23 \\
1,527\end{array}$ & $\begin{array}{l}\text { Dark-red } \\
\text { latosols }\end{array}$ \\
\hline
\end{tabular}

and washed free of surface soil; the quality assurance procedure for rhizome sampling of Le Duc et al. (2003) was followed. Both frond and rhizome samples were then dried at $80^{\circ} \mathrm{C}$ for $48 \mathrm{~h}$ and weighed.

\subsection{Assessment of literature data on biomass allocation in Pteridium}

In order to compare the Brazilian data with data obtained from other regions of the world, a Systematic Review using two literature databases was performed (Web of Science, Google Scholar), using "bracken" and "Pteridium" as key search terms. All papers identified were inspected, and a subset of papers that included data on biomass allocation was selected and the biomass data abstracted (see Table 2). Most papers contained data on the above-ground components; there was much less information about rhizomes so that comparisons were not viable.

\subsection{Data analysis}

Differences in P. esculentum subsp. arachnoideum performance between Brazilian ecosystems (Atlantic Forest and Savanna) were assessed between ecosystems using two-sample t-test with pooled variances of the Systat statistic package. In order to cope with errors on both axes and doesn't assume which is the dependent variable, reduced major axis regressions (RMA) were estimated to data derived from the two ecosystems using PAST (Hammer et al., 2001) and Spearman's correlation coefficients were calculated to assess the significance of these relationships. The comparisons of the slopes were performed through the analysis of covariance for RMA, using the significance of the Bartlett-corrected likelihood ratio statistic testing for common slope (LR), within the R statistical environment (R v.2.10.1, R Development Core Team, 2004).

In order to assess differences in resource partitioning, RMA regressions were fitted to the South American and European data (data abstracted from references in Table 2). The linear regressions obtained were compared through analysis of covariance as described above. The relationships were derived from the mean values for each variable at each site; where only a range was reported the average of the minimum and maximum value was used. 
Table 2. Comparative dataset on Pteridium biomass allocation derived from the literature from Europe, South America and this study.

\begin{tabular}{|c|c|c|c|c|c|}
\hline Region & Site/ecosystem & $\begin{array}{l}\text { Leaf density } \\
\left(\mathrm{m}^{-2}\right)\end{array}$ & $\begin{array}{l}\text { leaf length } \\
(\mathrm{cm})\end{array}$ & $\begin{array}{l}\text { Frond biomass } \\
\qquad\left(\mathrm{g} \mathrm{m}^{-2}\right)\end{array}$ & Source \\
\hline \multirow[t]{39}{*}{ Europe } & Bealieu heath & - & - & 892 & Pearsall and Gorham (1956) \\
\hline & Stony Cross & - & - & 1408 & Pearsall and Gorham (1956) \\
\hline & North Bentley & - & - & 1072 & Pearsall and Gorham (1956) \\
\hline & South Bentley & - & - & 848 & Pearsall and Gorham (1956) \\
\hline & Bowland Forest & - & - & 1104 & Pearsall and Gorham (1956) \\
\hline & Lakenheath grassland A & 1.5 & 31.5 & 5.9 & Watt (1964) \\
\hline & Lakenheath grassland B & 2.95 & 35.5 & 15.5 & Watt (1964) \\
\hline & Lakenheath grassland C & 22.85 & 64 & 183.5 & Watt (1964) \\
\hline & Lakenheath grassland D & 50.25 & 125 & 923.5 & Watt (1964) \\
\hline & Lakenheath grassland E & 31.05 & 47.5 & 167.5 & Watt (1964) \\
\hline & Weeting & 23 & 142.5 & 520 & Lowday and Marrs (1992) \\
\hline & Cavenham & 24 & 100 & 385 & Marrs et al. (1998) \\
\hline & Stanford PTA. Norfolk & 35 & & 590 & Pakeman and Marrs (1994) \\
\hline & Mull & 32 & 132.1 & 533 & Paterson et al. (1997) \\
\hline & Sourhope & 31.5 & 87 & 382.5 & Paterson et al. (1997) \\
\hline & Lake District & 32.5 & 71.5 & 346 & Paterson et al. (1997) \\
\hline & Clywd & 28.5 & 111 & 546 & Paterson et al. (1997) \\
\hline & Breckland & 31 & 76.5 & 371 & Paterson et al. (1997) \\
\hline & Devon & 15.5 & 113 & 322 & Paterson et al. (1997) \\
\hline & Lindale & - & - & 985 & Lawson et al. (1986) \\
\hline & Sourhope 1 & 58.8 & 56.5 & 391.3 & Le Duc et al. (2000) \\
\hline & Souhope 2 & 26.5 & 69.9 & 297.5 & Le Duc et al. (2000) \\
\hline & Peak & 42.6 & 91.1 & 521.9 & Le Duc et al. (2000) \\
\hline & Carneddau & 44 & 74.1 & 537.6 & Le Duc et al. (2000) \\
\hline & Cannock 1 & 36.8 & 105.9 & 676.4 & Le Duc et al. (2000) \\
\hline & Cannock 2 & 29.7 & 73.7 & 294.2 & Le Duc et al. (2000) \\
\hline & Open & 15.4 & 245 & 731.1 & den Ouden (2000) \\
\hline & Larix woodland & 8.1 & 241 & 313.5 & den Ouden (2000) \\
\hline & Larix woodland & 8.5 & 216 & 316.5 & den Ouden (2000) \\
\hline & Larix woodland & 6.1 & 203 & 207.7 & den Ouden (2000) \\
\hline & Larix woodland & 6.2 & 193 & 136.8 & den Ouden (2000) \\
\hline & Larix woodland & 6.4 & 165 & 175.9 & den Ouden (2000) \\
\hline & Pinus woodland & 7 & 210 & 234.2 & den Ouden (2000) \\
\hline & Pinus woodland & 3.1 & 213 & 101.9 & den Ouden (2000) \\
\hline & Pinus woodland & 12.9 & 129 & 177.8 & den Ouden (2000) \\
\hline & Quercus woodland & 3.4 & 174 & 79.4 & den Ouden (2000) \\
\hline & Quercus woodland & 3.7 & 216 & 135.4 & den Ouden (2000) \\
\hline & Quercus woodland & 3.9 & 176 & 104.4 & den Ouden (2000) \\
\hline & Quercus woodland & 4.4 & 136 & 79.7 & den Ouden (2000) \\
\hline \multirow[t]{12}{*}{ S. America } & $\begin{array}{l}\text { Venezuelan montane } \\
\text { savanna }\end{array}$ & 5.1 & 89 & 287.4 & $\begin{array}{l}\text { Alonso-Amelot and } \\
\text { Rodulfo-Baechler (1996) }\end{array}$ \\
\hline & $\begin{array}{l}\text { Venezuelan montane } \\
\text { savanna }\end{array}$ & 1.6 & 76.59 & 53.2 & $\begin{array}{l}\text { Alonso-Amelot and } \\
\text { Rodulfo-Baechler (1996) }\end{array}$ \\
\hline & EEI & 20.4 & 146 & $1,236.0$ & This study \\
\hline & PEPF & 17.6 & 231 & $1,448.8$ & This study \\
\hline & RECOR1 & 9.6 & 243 & 481.2 & This study \\
\hline & RECOR2 & 4.6 & 147 & 522.0 & This study \\
\hline & UFSCar1 & 13.6 & 321 & $1,178.9$ & This study \\
\hline & UFSCar2 & 10.4 & 180 & 933.9 & This study \\
\hline & PEJ & 19.2 & 190 & $1,610.0$ & This study \\
\hline & PECE & 10.4 & 288 & 817.3 & This study \\
\hline & PEIC & 20.0 & 184 & $1,179.4$ & This study \\
\hline & PECB & 10.4 & 209 & 951.9 & This study \\
\hline
\end{tabular}




\section{Results}

\subsection{Biomass allocation in Brazilian P. esculentum subsp. arachnoideum}

There were no significant differences between the ecosystems for all variables: frond biomass, rhizome biomass, necromass, frond density, and frond length (see Table 3). Frond biomass was very variable in the Savanna and in the Atlantic Rain Forest, ranging from 114-2353 $\mathrm{g} \mathrm{m}^{-2}$ and from $284-1912 \mathrm{~g} \mathrm{~m}^{-2}$, respectively. A similar pattern was found for necromass (Savanna $=0-2970 \mathrm{~g} \mathrm{~m}^{-2}$; Atlantic Rain Forest $=213-2264 \mathrm{~g} \mathrm{~m}^{-2}$ ). Leaf density and rhizome biomass, however, did not show as extreme a pattern as these other two variables. Savanna still had the greatest variability (1-28 leaves $\mathrm{m}^{-2}$ ) overlapping the ranges of the Atlantic Rain Forest (4-20 leaves $\mathrm{m}^{-2}$ ), and rhizome biomass ranging from 23.5 to $2757 \mathrm{~g} \mathrm{~m}^{-2}$ in the Savanna and from 219 to $1477 \mathrm{~g} \mathrm{~m}^{-2}$ in the Atlantic Rain Forest. Length of expanded leaf ranged from 0.5 to $4.2 \mathrm{~m}$ in the Savanna, and from 1 to $4.1 \mathrm{~m}$ in the Atlantic Rain Forest.

When all data were combined, significant positive relationships were found between: (1) frond and rhizome biomass and (2) frond biomass and necromass, while no relationship was observed between the rhizome/frond biomass ratio and necromass (see Table 4). Additionally, considering the ecosystem types, positive relationships were significant only for the Savanna (see Figure 1, Table 4).

There were no significant ecosystems differences in the slopes of the relationship between (1) rhizome and frond biomass $(\mathrm{LR}=3.050, \mathrm{p}=0.080)$, (2) rhizome biomass and necromass $(\mathrm{LR}=1.056, \mathrm{p}=0.304)$, and (3) leaf density and frond biomass $(\mathrm{LR}=0.749, \mathrm{p}=0.387)$. On the other hand, there were significant differences in the slopes of the relationships between (1) frond biomass and necromass $(\mathrm{LR}=6.651, \mathrm{p}=0.010)$, albeit weakly, (2) rhizome/frond biomass and necromass ( $\mathrm{LR}=7.900$, $\mathrm{p}=0.005$ ) and ( 3 ) frond biomass and total biomass $(\mathrm{LR}=4.186, \mathrm{p}=0.041)$.

\subsection{Comparison of biomass allocation in Pteridium between South-America and Europe}

A comparison of absolute values (see Table 2) showed that frond density is, in general, greater in Europe than in South America (t-test, $\mathrm{t}=2.55, \mathrm{p}=0.015$ ). However, leaf length ( $\mathrm{t}=2.82, \mathrm{p}=0.007)$, frond biomass $(\mathrm{t}=4.0, \mathrm{p}=0.002)$, and leaf biomass $(\mathrm{t}=8.04, \mathrm{p}<0.001)$, calculated by dividing the total frond biomass $\left(\mathrm{g} \mathrm{m}^{-2}\right)$ by leaf density (leaves $\mathrm{m}^{-2}$ ), were significantly greater in the South American samples. The range of frond lengths from both regions showed substantial overlap, but the European fronds were in the lower part of the range and the South American fronds in the upper part.

The relationship between European variables indicated a negative significant relationship between (1) leaf density and leaf length and (2) leaf length and leaf biomass, whereas a positive relationship was detected between leaf density and leaf biomass (see Figure 2 and Table 4). We observed significant relationship for data from South America only between density and leaf biomass ( $L R=11.903, p=0.0006)$. There was no significant difference in the slope for the relationship between (1) leaf length and leaf biomass $(\mathrm{LR}=2.318, \mathrm{p}=0.128)$ and (2), leaf density and leaf length $(\mathrm{LR}=0.256, \mathrm{p}=0.613$ ) (see Figure 2).

\section{Discussion}

\subsection{Biomass allocation}

In Brazil Pteridium esculentum subsp. arachnoideumis is found in both Atlantic Forest and Savanna, suggesting that this species is able to colonize contrasting ecosystems habitat. There were no significant differences in frond biomass, frond length, frond density and litter biomass, but the significant differences found on the variances, in general greater in the Savanna, indicated differences between study sites rather than ecosystems. Because of its large area, Savanna includes a high diversity of soil types, climate and vegetation types (Silva et al., 2006). We could expect such variation as a function of these environmental heterogeneity.

Table 3. Biomass allocation in P. esculentum subsp. arachnoideum stands of different Brazilian ecosystems. Mean \pm SE, $\mathrm{t}$-values and significance $(\mathrm{p})$ values are presented;

\begin{tabular}{lcccc}
\hline \multicolumn{1}{c}{ Variable } & Savanna & Atlantic Forest & t & p \\
\hline Frond biomass & $966.8 \pm 104.9$ & $1139.6 \pm 116.8$ & 1.08 & 0.286 \\
Rhizome biomass* & $696.3 \pm 121.7$ & $795.2 \pm 85.4$ & 0.60 & 0.964 \\
Total biomass & $1663.1 \pm 183.8$ & $1934.8 \pm 171.1$ & 1.02 & 0.311 \\
Leaf biomass* & $88.5 \pm 11.7$ & $93.4 \pm 7.5$ & 0.33 & 0.742 \\
Density of leaves & $12.7 \pm 1.2$ & $12.8 \pm 1.3$ & 0.04 & 0.964 \\
Rhizome/frond biomass* & $0.8 \pm 0.15$ & $0.9 \pm 0.15$ & 0.31 & 0.760 \\
Leaf length* & $2.1 \pm 0.11$ & $2.1 \pm 0.08$ & 0.21 & 0.831 \\
Necromass* & $1073.1 \pm 161.6$ & $964.2 \pm 128.1$ & 0.53 & 0.600
\end{tabular}

*indicates unequal variances according to Levene's test $(\mathrm{p}<0.05)$. Biomass and necromass are given in $\mathrm{g} / \mathrm{m}^{2}$, density as the number of individual fronds $/ \mathrm{m}^{2}$ and mean frond length in $\mathrm{m}$. Fronds were considered as the whole group of leaves sampled at each plot. Number of samples was 30 for Savanna and 20 for the Atlantic Forest; 75 leaves were measured in the Atlantic Forest and 82 in Savanna. 
It has been suggested that the development of a complex rhizome system requires a substantial investment and with this comes a considerable measurable risk (de Kroon and van Groenendael, 1997). Our results suggest that a common rhizome mass is able to support a large variation in frond biomass, which can be expressed through differences in both frond density and frond length. In tropical areas we could expect more investment in above-ground biomass, as frond longevity is greater as a consequence of the less harsh climate and hence productivity should also be greater. (a)

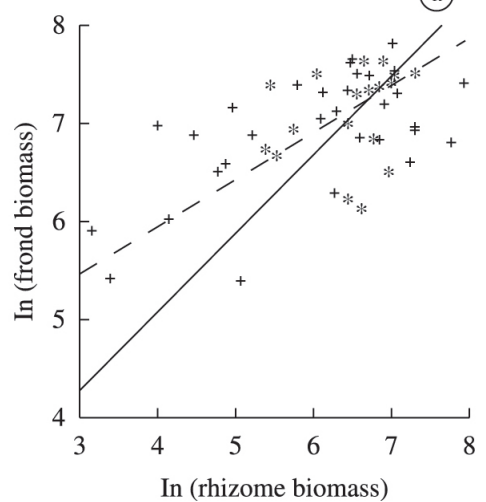

(b)

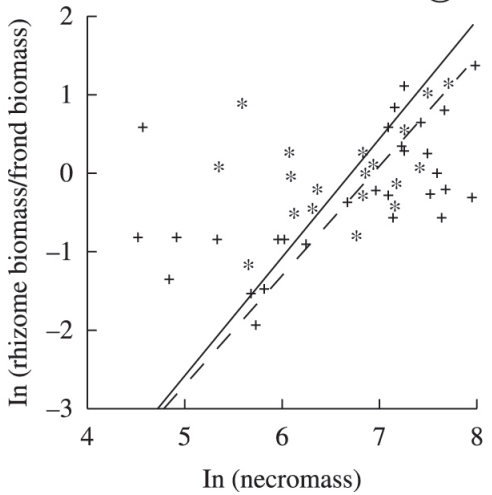

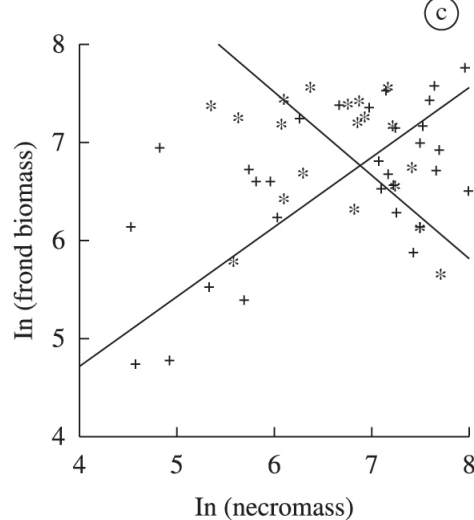

Figure 1. Relationships between production-related variables from Pteridium esculentum subsp. arachnoideum in all the points of sampling in Atlantic forest and Savanna ecosystems in Brazil: (a) Frond biomass vs Rhizome biomass, (b) Rhizome/ frond biomass ratio vs Necromass, and (c) Frond biomass vs Necromass. All data were ln transformed. Key: Savanna $=+$ and continuous line; Atlantic Forest= *and dashed line. Regression equations are shown in Table 4a. Frond biomass, rhizome biomass and necromass are given in $\mathrm{g}$ per $\mathrm{m}^{2}$.

Table 4. Parameters of the reduced major axis regression estimated for data illustrated in (a) Figure 1 and (b) Figure 2. Spearman's correlation coeficients $\left(\mathrm{r}_{\mathrm{s}}\right)$ and significance $(\mathrm{p})$ are presented.

(a) Number of samples was 30 for Savanna and 20 for the Atlantic Forest, all analyses were performed using In transformed data.

\begin{tabular}{|c|c|c|c|c|c|c|}
\hline Variables & Ecosystem & $\mathbf{a}$ & $\mathbf{b}$ & $\mathbf{R}_{\text {adjusted }}^{2}$ & $\mathbf{r}_{\mathrm{s}}$ & $\mathbf{p}$ \\
\hline Frond biomass vs & Combined & 0.65 & 1.18 & 0.32 & 0.437 & 0.002 \\
\hline \multirow[t]{2}{*}{ Rhizome biomass } & Savanna & 0.60 & 3.05 & 0.38 & 0.614 & $<0.001$ \\
\hline & Atlantic Forest & 1.00 & 0.38 & 0.09 & 0.308 & 0.186 \\
\hline \multirow{3}{*}{$\begin{array}{l}\text { Rhizome biomass/Frond } \\
\text { biomass vs Necromass }\end{array}$} & Combined & 0.77 & 0.95 & 0.17 & 0.227 & 0.121 \\
\hline & Savanna & 0.93 & -6.89 & 0.334 & 0.578 & 0.021 \\
\hline & Atlantic Forest & 1.01 & -7.15 & 0.137 & 0.370 & 0.108 \\
\hline \multirow{3}{*}{$\begin{array}{l}\text { Frond biomass } \\
\text { vs Necromass }\end{array}$} & Combined & 0.97 & -3.05 & 0.27 & 0.548 & $<0.001$ \\
\hline & Savanna & 0.72 & 1.80 & 0.33 & 0.618 & $<0.001$ \\
\hline & Atlantic Forest & -0.85 & 12.61 & 0.04 & -0.20 & 0.389 \\
\hline
\end{tabular}

(b) Number of samples was 32 for Europe and 12 for the South America, all analyses were performed using In transformed data.

\begin{tabular}{clccccc}
\hline \multicolumn{1}{c}{ Variables } & Continent & $\mathbf{a}$ & $\mathbf{b}$ & $\mathbf{R}_{\text {adjusted }}$ & $\mathbf{r}_{\text {s }}$ & $\mathbf{P}$ \\
\hline Leaf density vs Leaf length & Europe & -0.54 & 6.16 & 0.08 & -0.2758 & 0.12653 \\
& S. America & 0.57 & 3.88 & 0.459 & 0.677 & 0.0155 \\
& & & & & & \\
Leaf density vs Leaf biomass & Europe & 1.04 & 2.70 & 0.661 & 0.813 & 0.0001 \\
& S. America & 1.26 & 3.65 & 0.898 & 0.974 & 0.0001 \\
& & & & & & \\
Leaf length vs Leaf biomass & Europe & 1.89 & -3.51 & 0.10 & 0.321 & 0.073 \\
& S. America & 2.21 & -4.93 & 0.54 & 0.735 & 0.006 \\
\hline
\end{tabular}



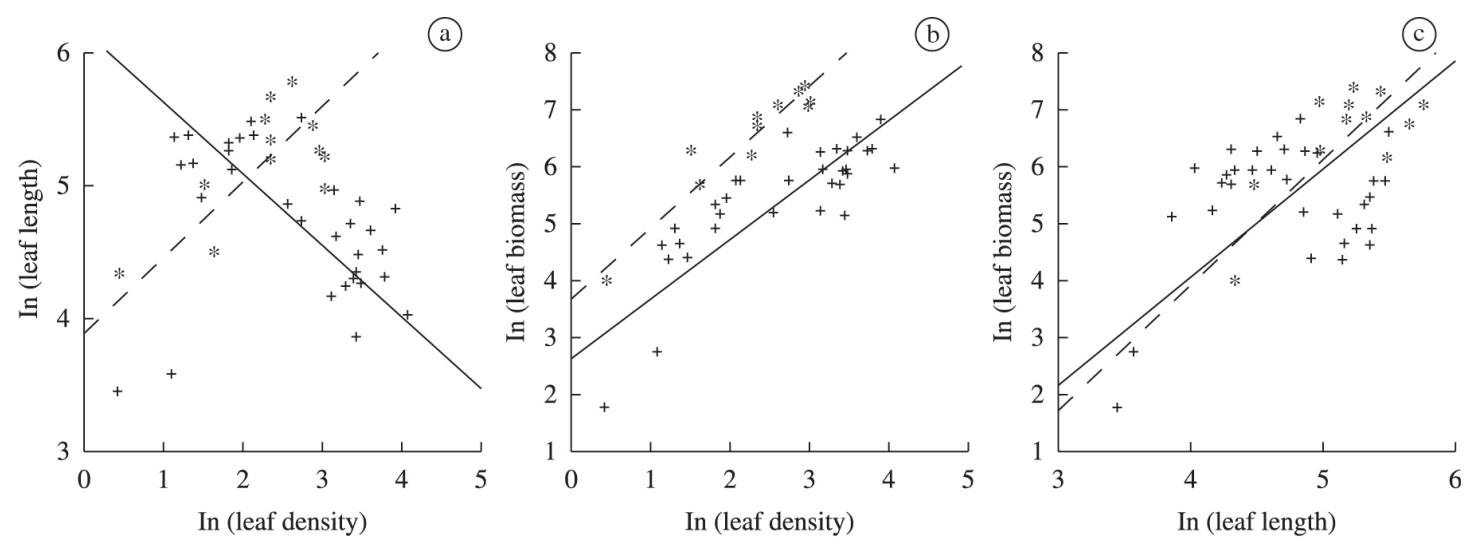

Figure 2. Relationships between production-related variables from Pteridium of South America and Europe: (a) leaf density vs leaf length, (b) leaf density vs leaf biomass and (c) leaf length vs leaf biomass. Brazilian data (Pteridium esculentum subsp. arachnoideum $)=*$ and continuous line; + and dashed line $=$ European data (Pteridium aquilinum). All data were $1 n$ transformed. Regression equations are shown in Table $4 \mathrm{~b}$. Leaf density is given by the number of leaves per $\mathrm{m}^{2}$, leaf length in $\mathrm{cm}$ and leaf biomass is the weight of individual leaf in $\mathrm{g}$.

Environmental heterogeneity in tropical ecosystems, in terms of canopy coverage, may be a factor determining the above-ground biomass variation, considering that individual ramets have to struggle for light, to maintain the productivity of the overall clone (Huber and Hutchings, 1997).

In terms of vegetation dynamics two important results were obtained. The first was the negative relationship between frond and litter biomass found to Atlantic Forest data, indicating that the dense litter layer developing under the P. esculentum subsp. arachnoideum may be harmful for its own regeneration, as first suggested by Watt (1945, 1947, 1976) as well as for other species (Marrs, 1988; Marrs et al., 2007). The second was the dense canopy of P. esculentum subsp. arachnoideum fronds which is also an important factor contributing to its ability to become a dominant species and being able to prevent the colonization by other species (Marrs, 1988; Marrs and Pakeman, 1995; Ghorbani et al., 2006). Both dense canopy cover and depth litter layer can also get one further problem with Pteridium colonization: the impoverishment of the soil seed bank (Ghorbani et al, 2006). A reduction in species present in the seed bank of Atlantic Forest was found in a previous study (Silva and Silva Matos, 2006).

Another direct consequence of such a deep litter layer (necromass) is that the risk and intensity of fire is increased in both ecosystems. Normally, natural fires occur in the Savanna every two to three years (Hoffmann, 1996), but nonnatural, human-induced fires are increasingly common albeit unpredictable including in the moist Atlantic Forest (Silva Matos et al., 2002, 2005). Unfortunately, the relationship of P. esculentum subsp. arachnoideum and fire in the Savanna is still unclear, but we might hypothesize that a positive feedback of fire on P. esculentum subsp. arachnoideum will develop: fire keeps the woody vegetation under control which allows $P$. esculentum subsp. arachnoideum to spread increasing its biomass, which in turn increases the risk, intensity and frequency of fire events, leading to the decrease in the biological diversity changing the structure of the community (Hoffmann and Moreira, 2002; Pivello, 2006).

These results are worrying because these are both ecosystem types of considerable international conservation importance (Myers et al., 2000) and the P. esculentum subsp. arachnoideum here exhibits a very large range of allocation responses, implying considerable plasticity, and hence must be viewed as a major potential future invasive threat.

\subsection{Comparison of biomass allocation between European and South American Pteridium}

Different biomass allocation strategies were detected between European and South American Pteridium. In Europe, the frond life-cycle is expected to last at most seven months in any given annual season because all fronds are killed by winter frost (Pakeman, et al., 1994; Pakeman and Marrs, 1996; Pottier, et al., 2005; Marrs and Watt, 2006), and there should therefore be less investment in fronds, in terms of biomass/length and biomass/density. In tropical South America, by the other hand, we could expect an increase of leaf biomass after the maximum length is attained as leaves live longer than in Europe. However, the higher slope observed in the leaf density $x$ leaf biomass relationship for the South America data, indicates that the increase of fronds causes a negative effect on the biomass allocation of $P$. arachnoideum. According to Weiner (2004) environmental selection pressures drive changes on plant resource allocation. So, in a large-scale comparison, between Brazil and Europe, we can assume that differences on the biomass allocation patterns resulted from different climate pressures and speciation, while in the comparison of Brazilian ecosystems such pattern resulted from small-scale environmental heterogeneity, as discussed earlier. This broad plasticity might have allowed Pteridium to develop as an invasive genus in diverse bioclimatic regions. 
For the conservation of endangered ecosystems Pteridium poses substantive actual and potential threats (Pakeman and Marrs, 1992). Its wide geographic range coupled with the environmental plasticity demonstrated here allows it to succeed in a wide range of habitats, and also makes it difficult to predict its invasiveness (Goodwin et al., 1999). As the Pteridium patch increases mainly through rhizome expansion (Marrs and Watt, 2006), it should be possible to control it by manipulating resource allocation between the rhizomes and fronds. In Europe, frond removal by cutting and other mechanical treatments is used routinely to control Pteridium. A similar approach should be even more effective in South America where there is a greater proportion of the resource allocated to the production of a large frond biomass. However, this strategy needs to be tested experimentally.

Acknowledgements - We thank S. Matos, A. Matos, M. Matos, A. Muller, P. Dodonov, A. de Paula, T. Sampaio e Silva, I. Silva, R. Miatto, C. Zanelli and L. Joaquim for help with field work, CNPq and FAPESP for scholarships (CNPq, R.O. Xavier) and (FAPESP, D.M. Silva Matos 2007/05658-3; F.C.S. Tiberio, 2007/07976-2, and FAPESP for part funding this project (2006/61570-5).

\section{References}

ALONSO-AMELOT, ME. and RODULFO-BAECHLER, S., 1996. Comparative spatial distribution, size, biomass and growth rate of two varieties of bracken fern (Pteridium aquilinum L. Kuhn) in a neotropical montane habitat. Vegetatio, vol. 125, p. 137-147. http://dx.doi.org/10.1007/BF00044647

ALONSO-AMELOT, ME. and OLIVEROS-BASTIDAS, A., 2005. Kinetics of the Natural Evolution of Hydrogen Cyanide in Plants in Neotropical Pteridium arachnoideum and its Ecological Significance. Journal of Chemical Ecology, vol. 31, p. 315-331. PMid:15856786. http://dx.doi.org/10.1007/s10886-005-1343-z

BRADSHAW, AD., 1963. The analysis of evolutionary process involved in the divergence of plant population. Proceedings of the International Congress of Genetics, vol. 1, p. 143.

CARNIER, E., 1991. Resource capture, biomass allocation and growth in herbaceous plants. Trends in Ecology and Evolution, vol. 6, p. 126-131. http://dx.doi.org/10.1016/0169-5347(91)90091-B

DE KROON, H. and VAN GROENENDAEL, JV., 1997. The ecology and evolution of clonal plants. Leiden: Backhuys Publishers.

DEN OUDEN, J., 2000. The role of bracken (Pteridium aquilinum) in forest dynamics. Netherlands: Wageningen University. $\mathrm{PhD}$ thesis.

FAN, JW., WANG, K., HARRIS, W., ZHONG, HP., HU, ZM., HAN, B., ZHANG, WY. and WANG, JB., 2009. Allocation of vegetation biomass across a climate-related gradient in the grassland of Inner Mongolia. Journal of Arid Environments, vol. 73, p. 521-528. http://dx.doi.org/10.1016/j.jaridenv.2008.12.004

FRANÇA, TN., TKARNIA, CH. and PEIXOTO, PV., 2002. Enfermidades determinadas pelo princípio radiométrico de Pteridium aquilinum (Polypodiaceae). Pesquisa Veterinária Brasileira, vol. 22, p. 85-96.

Fundação SOS Mata Atlântica and Instituto Nacional de Pesquisas Espaciais - INPE, 2009. Atlas dos remanescentes florestais da Mata Atlântica periodo 2005-2008. São Paulo: Fundação SOS.
GOODWIN, BJ., MCALLISTER, AJ. and FAHRIG, L., 1999. Predicting invasiveness of plant species based on biological information. Conservation Biology, vol. 13, p. 422-426. http:// dx.doi.org/10.1046/j.1523-1739.1999.013002422.x

GHORBANI, BJ., LE DUC, MG., MCALLISTER, HA., PAKEMAN, RJ. and MARRS, RH., 2006. Effects of the litter layer of Pteridium aquilinum on seed banks under experimental restoration. Applied Vegetation Science, vol. 9, p. 127-136. http://dx.doi.org/10.1658/14022001(2006)9[127:EOTLLO]2.0.CO;2

HARTIG, K. and BECK, E., 2003. The bracken fern (Pteridium arachnoideum (Kaulf.) Maxon) dilemma in the Andes of Southern Ecuador. Ecotropica, vol. 9, p. 3-13.

HAMMER, Ø., HARPER, D A.T. and RYAN, P.D., 2001. PAST: Paleontological Statistics Software Package for Education and Data Analysis. Palaeontologia Electronica, vol. 4, 9 p.

HOFFMANN, WA., 1996. The effects of fire and cover on seedling establishment in a neotropical savanna. Journal of Ecology, vol. 84, p. 383-393. http://dx.doi.org/10.2307/2261200

HOFFMANN, WA. and MOREIRA, AG., 2002. The role of fire in population dynamics of woody plants. In OLIVEIRA, P.S. and MARQUIS, RJ. (Eds.). The Cerrados of Brazil-Ecology and Natural Hystory of a Neotropical Savanna. New York: Columbia University Press. p. 159-177.

HUBER, H. and HUTCHINGS, MJ., 1997. Differential response to shading in orthotropic and plagiotropic shoots of the clonal herb Glechoma hirsuta. Oecologia, vol. 112, p. 465-491. http:// dx.doi.org/10.1007/s004420050336

JIMÉNEZ-AMBRIZ, G., PETIT, C., BOURRIÉ, I., DUBOIS, S., OLIVIERI, I. and RONCE, O., 2007. Life history variation in the heavy metal tolerant plant Thlaspi caerulescens growing in a network of contaminated and noncontaminated sites in southern France: role of gene flow, selection and phenotypic plasticity. New Phytologist, vol. 173, p. 199-215. PMid:17176406. http:// dx.doi.org/10.1111/j.1469-8137.2006.01923.x

LAWSON, GJ., CALLAGHAN, TV. and SCOTT, R., 1986. Bracken as an energy resource. In Smith, RT. and Taylor, JA. (Ed.). Bracken: ecology, land use and control technology. Carnforth: Parthenon. p. 239-248.

LE DUC, MG., PAKEMAN, RJ. and MARRS, RH., 2000. Vegetation development on upland and marginal land treated with herbicide, for bracken (Pteridium aquilinum) control, in Great Britain. Journal of Environmental Management, vol. 58, p. 147-160. http://dx.doi.org/10.1006/jema.1999.0321

,- 2003 . Changes in the rhizome system of bracken when subject to long-term experimental treatment. Journal of Applied Ecology, vol. 40, p. 508-522. http://dx.doi.org/10.1046/j.1365-2664.2003.00818.x

LOWDAY, JE. and MARRS, RH., 1992. Control of Bracken and the Restoration of Heathland. I. Control of Bracken. Journal of Applied Ecology, vol. 29, p. 195-203. http://dx.doi.org/10.2307/2404361

MARÇAL, WS., GASTE, L., REICHERT-NETTO, NC. and MONTEIRO, FA., 2002. Intoxicação aguda pela samambaia (Pteridium aquilinum, L. Kuhn) em bovinos da raça Aberdeen angus. Archives of Veterinary Science, vol. 7, p. 77-81.

MARÇAL WS., 2003. A intoxicação por samambaia em bovinos criados no estado do Paraná. Semina: Ciências Agrárias, vol. 24, p. 197-208. http://dx.doi.org/10.5433/1679-0359.2003v24n1p197 
MARRS, RH., 1988. Vegetation change on lowland heaths and its relevance for conservation management. Journal of Environmental Management, vol. 26, p. 127149.

MARRS, RH. and PAKEMAN, RJ., 1995. Bracken invasion: lessons from the past and prospects for the future. In THOMPSON DBA., HESTER AJ. and USHER MB. (Ed.). Heaths and moorlands: cultural landscape. Edinburgh: HMSO. 180-193.

MARRS, RH., JOHNSON, SW. and LE DUC, MG., 1998. Control of bracken and restoration of heathland. VII. Effects of bracken control treatments on the rhizome and its relationship with frond performance. Journal of Applied Ecology, vol. 35, p. 748-757.

MARRS, RH. and WATT, AS., 2006. Biological Flora of the British Isles: Pteridium aquilinum (L.) Kuhn. Journal of Ecology, vol. 94, p. 1272-1321. http://dx.doi.org/10.1111/j.1365-2745.2006.01177.x

MARRS, RH., GALTRESS, K., TONG, C., BLACKBIRD, SJ., HEYES, TJ., PAKEMAN, RJ. and LE DUC, MG., 2007. Conflicts between competing conservation goals, biodiversity or ecosystem services: quantification of element losses and species recruitment using a moorland-bracken model system. Journal of Environmental Management, vol. 85, p. 1034-1047. PMid:17207569. http:// dx.doi.org/10.1016/j.jenvman.2006.11.011

MCCARTHY, MC. and ENQUIST, BJ., 2007. Consistency between an allometric approach and optimal partitioning theory in global patterns of plant biomass allocation. Functional Ecology, vol. 21, p. 713-720. http://dx.doi.org/10.1111/j.1365-2435.2007.01276.x

MCCONNAUGHAY, KD.M. and COLEMAN, JS., 1999. Biomass allocation in plants: ontogeny or optimally? A test along three resource gradients. Ecology, vol. 80, p. 2581-2593. http://dx.doi. org/10.1890/0012-9658(1999)080[2581:BAIPOO]2.0.CO;2

MIATTO, RC., SILVA, IA., SILVA-MATOS, DM. and MARRS, RH., 2011. Woody vegetation structure of Brazilian Cerrado invaded by Pteridium arachnoideum (Kaulf.) Maxon (Dennstaedtiaceae). Flora - Morphology, Distribution, Functional Ecology of Plants, vol. 206, p. 757-762. http://dx.doi.org/10.1016/j.flora.2010.12.001

MINER, BG., SULTAN, SE., MORGAN, SG., PADILHA, DK. and RELYA, RA., 2005 Ecological consequences of phenotypic plasticity. Trends in Ecology and Evolution, vol. 20, p. 685-692. PMid:16701458. http://dx.doi.org/10.1016/j.tree.2005.08.002

MULLER, I., SCHMID, B. and WEINER, J., 2000. The effectof nutrient availability on biomass allocation patterns in 27 species of herbaceous plants. Perspectives in Plant Ecology, Evolution and Systematics, vol. 3, p. 115-127. http://dx.doi.org/10.1078/14338319-00007

MYERS, N., MITTERMEIER, RA., MITTERMEIER, CG., FONSECA, G A.B. and JENNIFER, K., 2000. Hotspots Biodiversity hotspots for conservation priorities. Nature, vol. 403, p. 853-858. PMid:10706275. http://dx.doi.org/10.1038/35002501

Nature Conservancy, 2010. Nearly one in every four plant species on Earth can be found in Brazil. Available from: <http://www. nature.org/wherewework/southamerica/brazil/work/art5082. htmll>. Access in: 10 Feb 2010.

NIKLAS, KJ., 2005. Modelling Below- and Above-ground Biomass for Non-woody and Woody Plants. Annals of Botany, vol. 95, p. 315-321. PMid:15546927. http://dx.doi.org/10.1093/aob/mci028

PAKEMAN, RJ. and MARRS, RH., 1992. The conservation of bracken, Pteridium aquilinum (L.) Kuhn) - dominated communities in the UK, and an assessment of the ecological impact of bracken expansion or its removal. Biological Conservation, vol. 62, p. 101-114. http://dx.doi.org/10.1016/0006-3207(92)90931-C
-, 1996. Modelling the effects of climate change on the growth of bracken (Pteridium aquilinum) in Britain. Journal of Applied Ecology, vol. 33, p. 561-575. http://dx.doi.org/10.2307/2404985

PAKEMAN, RJ., MARRS, RH. and JACOB, PJ., 1994. A model of bracken (Pteridium aquilinum) growth and the effects of control strategies and changing climate. Journal of Applied Ecology, vol. 31 , p. 145154

PAKEMAN, RJ. and MARRS, RH., 1994. The effects of control on the biomass, carbohydrate content and bud reserves of bracken (Pteridium aquilinum (L.) Kuhn), and an evaluation of a bracken growth model. Annals of Applied Biology, vol 124, no 3, p. 479-493. http://dx.doi.org/10.1111/j.1744-7348.1994.tb04153.x

PATERSON, S., PAKEMAN, RJ. and MARRS, RH., 1997. Evaluation of a bracken (Pteridium aquilinum (L.) Kuhn) growth model in predicting the effects of control strategies across a range of climatic zones in Great Britain. Annals of Applied Biology, vol. 130, p. 305-318. http://dx.doi.org/10.1111/j.1744-7348.1997. tb06834.x

PEARSALL, WH. and GORHAM, E., 1956. Production Ecology I. Standing Crops of Natural Vegetation. Oikos, vol. 7, p. 193-201.

PEREIRA, AC. and GAMA, VF., 2010. Anthropization on the Cerrado biome in the Brazilian Uruçuí-Una Ecological Station estimated from orbital images. Brazilian Journal of Biology, vol. 70, p. 969-976. PMid:21180901. http://dx.doi.org/10.1590/ S1519-69842010000500008

PIVELLO, VR., 2006. Fire management for biological conservation in the Brazilian cerrado. In MISTRY, J. and BERARDI, A. (Eds.). Savannas and Dry Forests - Linking People with Nature. Ashgate, Hants. p. 129-154.

POTTIER, J., PAKEMAN, RJ., LE DUC, MG. and MARRS, RH., 2005. Validation of a model for predicting Pteridium aquilinum (L.) Kuhn production and control across the UK $B C P C$. International Congress - Crop Science and Technology, vol. 200, p. 987-994.

R Development Core Team, 2004. R: A Language and Environment for Statistical Computing. Vienna: R Foundation for Statistical computing. Available from: <http://www.r-project.org $>$.

REJMANEK, M., 2011. Invasiveness. In SIMBERLOFF, D. and REJMÁNEK, M. (Eds.). Encyclopedia of Biological Invasions. Berkeley and Los Angeles: University of California Press.

RICHARDS, CL., BOSSDORF, O., MUTH, NZ., GUREVITCH, J. and PIGLIUCCI, M., 2006. Jack of all trades, master of some? On the role of fhenotypic plasticity in plant invasions. Ecology Letters, vol. 9, p. 981-993. PMid:16913942. http://dx.doi. org/10.1111/j.1461-0248.2006.00950.x

SHIPLEY, B. and MEZIANE, D., 2002. The balanced-growth hypothesis and the allometry of leaf and root biomass allocation. Functional Ecology, vol. 16, p. 326-331. http://dx.doi.org/10.1046/ j.1365-2435.2002.00626.x

SILVA, JF., FARIÑAS, MR., FELFILI, JM. and KLINK, CA., 2006. Spatial heterogeneity, land use and conservation in the cerrado region of Brazil. Journal of Biogeography, vol. 33, p. 536-548. http://dx.doi.org/10.1111/j.1365-2699.2005.01422.x

SILVA MATOS, DM. and BELINATO, TA., 2010. Interference of Pteridium arachnoideum (Kaulf.) Maxon. (Dennstaedtiaceae) on the establishment of rainforest trees. Brazilian Journal of Biology, vol. 70, no. 2, p. 311-316. PMid:20549062. http://dx.doi. org/10.1590/S1519-69842010000200012

SILVA MATOS, DM., FONSECA, GDFM. and SILVA-LIMA, L., 2005. Differences on post-fire regeneration of the pioneers 
Cecropia glazioui and Trema micrantha in a lowland Brazilian Atlantic Forest. Revista de Biologia Tropical, vol. 53, p. 1-4.

SILVA MATOS, DM., SANTOS, CJ. and CHEVALIER, DR., 2002. Fire and restoration of the largest urban forest of the world in Rio de Janeiro City, Brazil. Urban Ecosystem, vol. 6, p. 151161. http://dx.doi.org/10.1023/A:1026164427792

SILVA, USR. and SILVA MATOS, D.M., 2006. The invasion of Pteridium aquilinum and the impoverishment of the seed bank in fire prone areas of Brazilian Atlantic Forest. Biodiversity and Conservation, vol. 15, p. 3035-3043. http://dx.doi.org/10.1007/ s10531-005-4877-z

STUEFER, JF., VAN HULZEN, JB. and DURING, HJ., 2002. A genotypic trade-off between the number and size of clonal offspring in the stoloniferous herb Potentilla reptans. Journal of Evolutionary Biology, vol. 15, p. 880-884. http://dx.doi. org/10.1046/j.1420-9101.2002.00435.x

THOMSON, JA., 2012. Taxonomic Status of Diploid Southern Hemisphere Brackens (Pteridium: Dennstaedtiaceae). Telopea, vol. 14, p. 43-48. http://dx.doi.org/10.7751/telopea2012007

THOMSON, JA. and ALONSO-AMELOT, ME., 2002. Clarification of the taxonomic status and relationships of Pteridium caudatum (Dennstaedtiaceae) in Central and South America. Botanical
Journal of the Linnean Society, vol. 140, p. 237-248. http://dx.doi. org/10.1046/j.1095-8339.2002.00089.x

WATT, AS., 1945. Contributions to the ecology of bracken (Pteridium aquilinum) III. Frond types and the make-up of the population. New Phytologist, vol. 44, p. 156-178 http://dx.doi. org/10.1111/j.1469-8137.1945.tb05029.x

-, 1947. Pattern and process in the plant community. Journal of Ecology, vol. 35, p. 1-22. http://dx.doi.org/10.2307/2256497

-, 1964. Some factors affecting bracken in Breackland. Journal of Ecology, vol. 52, p. 63-77. http://dx.doi.org/10.2307/2257783

-, 1976. The ecological status of bracken. Botanical Journal of the Linnean Society, vol. 73, p. 217-239. http://dx.doi. org/10.1111/j.1095-8339.1976.tb02023.x

WEINER J., 2004. Allocation, plasticity and allometry in plants. Perspectives in Plant Ecology, Evolution and Systematics, vol. 6, p. 207-215. http://dx.doi.org/10.1078/1433-8319-00083

YANG, Y., FANG, J., JI, C. and HAN, W., 2009. Above- and belowground biomass allocation in Tibetan grasslands. Journal of Vegetation Science, vol 20, no 1, p. 177-184. http://dx.doi. org/10.1111/j.1654-1103.2009.05566.x 